I nt erstiti al cel Is of Caj al are i nnervated by nitrergi c nerves and express nitric oxi de- sensi ti ve guanyl at e cycl ase i $n$ the gui nea pi g gast roi nt est i nal tract.

\begin{tabular}{|l|l|}
\hline 著者 & $\begin{array}{l}\text { I I NO Sat oshi, HORI GUCH Kazuhi de, NOJYO } \\
\text { Yoshi aki }\end{array}$ \\
\hline $\begin{array}{l}\text { j our nal or } \\
\text { publ i cat i on ti t l e }\end{array}$ & Neur osci ence \\
\hline vol une & 152 \\
\hline number & 2 \\
\hline page r ange & $437-448$ \\
\hline year & 2008 03 18 \\
\hline URL & ht t p: //hdl . handl e. net /10098/1667 \\
\hline
\end{tabular}




\title{
Interstitial cells of Cajal are innervated by nitrergic nerves and express nitric oxide-sensitive guanylate cyclase in the guinea pig gastrointestinal tract
}

\author{
Satoshi Iino, Kazuhide Horiguchi, Yoshiaki Nojyo \\ Department of Morphological and Physiological Sciences, \\ University of Fukui Faculty of Medical Sciences, \\ Eiheiji, Fukui 910-1193 JAPAN
}

Corresponding author : Satoshi Iino, M.D. Ph.D.

Department of Morphological and Physiological Sciences, University of Fukui Faculty of Medical Sciences, Eiheiji, Fukui 910-1193 JAPAN

TEL : 81-776-61-8301

FAX : 81-776-61-8132

e-mail : iinosa@u-fukui.ac.jp

Number of: $\quad$ Text pages: 32

Figures: 7

Table: 1

Acknowledgement

Supported by Grant-in-Aid for Scientific Research from Japan Society for Promotion of Science, The Japan Health Foundation and The Kazato Research Foundation. 


\section{ABSTRACT}

Nitric oxide (NO) is a major signaling molecule in the gastrointestinal tract, and released NO inhibits muscular contraction. The actions of NO are mediated by stimulation of soluble guanylate cyclase (sGC, NO-sensitive GC) and a subsequent increase in cGMP concentration. To elucidate NO targets in the gastrointestinal musculature, we investigated the immunohistochemical localization of the $\beta 1$ and $\alpha 1$ subunits of sGC and the distribution of neuronal NO synthase (nNOS)-containing nerves in the guinea pig gastrointestinal tract. Distinct immunoreactivity for sGC $\beta 1$ and sGC $\alpha 1$ was observed in the interstitial cells of Cajal (ICC), fibroblast-like cells (FLC) and enteric neurons in the musculature. Double immunohistochemistry using anti-c-Kit antibody and anti-sGC $\beta 1$ antibody revealed sGC $\beta 1$ immunoreactivity in almost all intramuscular ICC throughout the entire gastrointestinal tract. Immunoelectron microscopy revealed that sGC $\beta 1$-immunopositive cells possessed some of the criteria for intramuscular ICC: presence of caveolae; frequently associated with nerve bundles; and close contact with smooth muscle cells. sGC $\beta 1$-immunopositive ICC were closely apposed to nNOS-containing nerve fibers in the muscle layers. Immunohistochemical and immunoelectron microscopical observations revealed that FLC in the musculature also showed sGC $\beta 1$ immunoreactivity. FLC were often associated with nNOS-immunopositive nerve fibers. In the myenteric layer, almost all myenteric ganglia contained nNOS-immunopositive nerve cells and were surrounded by myenteric ICC and FLC. Myenteric ICC in the large intestine and FLC in the entire gastrointestinal tract showed sGC $\beta 1$ immunoreactivity in the myenteric layer. Smooth muscle cells in the stomach and colon showed weak sGC $\beta 1$ immunoreactivity, and those in the muscularis mucosae and vasculature also showed evident immunoreactivity. These data suggest that ICC are primary targets for NO released from nNOS-containing enteric neurons, and that some NO signals are received by FLC and smooth muscle cells in the gastrointestinal tract.

Key words: ICC, enteric nervous system, smooth muscle, fibroblast, nitric oxide synthase, cGMP 


\section{INTRODUCTION}

Nitric oxide (NO) is an unstable free radical and diffuses freely across biological membranes and reaches its targets to mediate downstream effects. The main target molecule of NO is soluble guanylate cyclase (sGC, NO-sensitive GC), which is composed of a cytosolic heterodimer of $\alpha(\alpha 1$, $\alpha 2)$ and $\beta(\beta 1, \beta 2)$ subunits (Koesling et al., 2004; Cary et al., 2006). Upon NO binding, activated sGC catalyzes the formation of cyclic guanosine 3',5'-monophospate (cGMP) from guanosine 5'-triphosphate (GTP). cGMP is then involved in the activation of a variety of effectors, such as cGMP-dependent protein kinases, phosphodiesterases and cyclic nucleotide-gated ion channels (Hofmann et al., 2000; Pyriochou and Papapetropoulos, 2005; Mergia et al., 2006).

NO is produced from L-arginine by one of three nitric oxide synthase (NOS) enzymes, namely, neuronal NOS (nNOS, NOS1), endothelial NOS (eNOS, NOS3) and inducible NOS (iNOS, NOS2) (Krumenacker et al., 2004). The role of NOS in the gastrointestinal (GI) tract depends largely on its localization. nNOS is primarily expressed in neurons, eNOS in vascular endothelium and iNOS in macrophages (Dijkstra et al., 2004; Toda and Herman, 2005). NO signaling is one of the most important pathways in the GI musculature (Van Geldre and Lefebvre, 2004; Toda and Herman, 2005). Previous studies have suggested that elevated levels of cGMP produced by sGC mediate the inhibitory actions of NO in the electrical and mechanical activities of smooth muscle, and promote relaxation of the GI musculature (Ward et al., 1992; Franck et al., 1997; Kim et al., 2003; De Man et al., 2007). Although biochemical studies have detected changes in cGMP levels in GI muscles (Ward et al., 1992), these are complex tissues containing several cell types. To clarify the mechanism of NO signal transduction in the GI musculature, it is important to determine which cells are responsible for the increases in cGMP levels induced by NO.

The interstitial cells of Cajal (ICC) are GI pacemaker cells that generate and propagate electrical slow waves, and are intermediates in enteric motor neurotransmission in the GI musculature (Sanders, 1996; Rumessen and Vanderwinden, 2003; Ward et al., 2004; Iino and Horiguchi, 2006). ICC show a highly branched morphology and form unique networks as myenteric ICC at the level of the myenteric plexus (ICC-MY), as intramuscular ICC in the musculature (ICC-IM), and as ICC in the deep muscular plexus layer of the small intestine (ICC-DMP). ICC-SM are distributed along the submucosal surface of the circular muscle layer of the colon. ICC-MY and ICC-SM serve as electrical pacemakers, generating slow waves, whereas ICC-IM and ICC-DMP are mediators of enteric motor neurotransmission. ICC express many of the signal transduction molecules acting downstream of the binding of neurotransmitters (Vannucchi, 1999; Epperson et al., 2000; Rumessen and Vanderwinden, 2003; Iino and Horiguchi, 2006; Chen et al., 2007), such as tachykinins, acetylcholine, vasoactive intestinal polypeptide, and NO. Functional and 
morphological evidence suggests that ICC may play a role in NO-dependent signal transduction. For example, ICC-IM are closely associated with varicose nerve terminals of enteric motor neurons with nNOS immunoreactivity (Wang et al., 1999, 2000; Ward et al., 2000). Physiologically, muscles lacking ICC-IM have been shown to have reduced inhibitory post-junctional responses to nerve stimulation (Burns et al., 1996; Ward et al., 1998, 2000; Beckett et al., 2002). From these observations, ICC-IM are considered to be the primary targets for NO signaling.

To elucidate NO targets in the GI musculature, we need to investigate the cellular localization of the NO-sensitive molecule sGC. A study of sGC $\beta 1$ subunit-deficient mice showed that the $\beta 1$ subunit regulated expression of the $\alpha$ subunits, and was essential for sGC function (Friebe et al., 2007). This study provides information on the immunohistochemical localization of the abundant subunits sGC $\beta 1$ and sGC $\alpha 1$ in the guinea pig GI tract. Using an anti-c-Kit antibody to detect ICC (Burns et al., 1997; Rumessen and Vanderwinden, 2003; Iino and Horiguchi, 2006), we investigated the possibility that ICC are preferential targets of NO signaling in the GI musculature. 


\section{EXPERIMENTAL PROCEDURES}

Adult female Hartley guinea pigs aged 4-6 weeks and weighing 200-400 g (Japan SLC, Japan) were used in this study. The use and treatment of animals followed the Guidelines for Animal Experiments, University of Fukui Faculty of Medical Sciences. All efforts were made to minimize the number of animals used and their suffering. All guinea pigs were anesthetized with an intraperitoneal injection of sodium pentobarbital (50 mg/kg) and the GI tract was dissected out.

For immunohistochemistry, we used following antibodies: rabbit anti-soluble guanylate cyclase $\beta 1$ (sGC $\beta 1$, G4405; Sigma, USA), rabbit anti-soluble guanylate cyclase $\alpha 1$ (sGC $\alpha 1$, G4280; Sigma), goat anti-c-Kit (SC-168; Santa Cruz, USA), sheep anti-neuronal nitric oxide synthase (nNOS, Dr PC Emson, The Babraham Institute, UK) (Herbison et al., 1996). Alexa Fluor 488-coupled donkey anti-IgG (Molecular Probes; USA) and Alexa Fluor 555-coupled donkey anti-IgG (Molecular Probes) were used as secondary antibodies. Control tissues were prepared by either omitting primary or secondary antibodies from the incubation solutions, and no specific immunoreactivity was observed.

For cryostat studies (Iino and Nojyo, 2006), GI tract was flushed with 0.01 M phosphate buffered saline (PBS, pH7.3) before being pinned to the Sylgard elastomer (Dow Corning Corp., USA) floor of a dissecting dish, stretched to $100 \%$ of their resting length, and then fixed with Zamboni's fixative (2\% paraformaldehyde made up in a 1.5\% saturated picric acid solution, $0.1 \mathrm{M}$ phosphate buffer, $\mathrm{pH}$ 7.3) for 4 hours at room temperature. Following fixation, tissues were washed with PBS, immersed in 30\% sucrose containing PBS and embedded in Tissue-Tek (Miles, USA) before being quickly frozen. Cryostat sections were cut at $12 \mu \mathrm{m}$ thickness using a Leica CM3050 cryostat and collected on poly-L-lysine-coated glass slides. Sections were preincubated with normal donkey serum (5\% in PBS) for 1 hour before being incubated with anti-sGC $\beta 1$ (1:1000), anti-sGC $\alpha 1$ (1:1000), anti-c-Kit (1:1000) and anti-nNOS (1:4000) antibodies at room temperature overnight. After sections had been incubated with primary antibodies, they were washed with PBS for at least 1 hour, before incubation in secondary antibodies (Alexa Fluor-coupled donkey anti-IgG, 1:500 in PBS) for 1 hour at room temperature. After washing with PBS, specimens were mounted with PermaFluor Aqueous Mounting Medium (Thermo Electron Corporation, USA).

For whole-mount preparations (Iino and Nojyo, 2006), tissues were placed in and flushed with PBS, pinned to the Sylgard floor of a dissecting dish and stretched to $130 \%$ of their resting length before being fixed with Zamboni's fixative for 4 hours at room temperature. The stretched tissues were washed with PBS and the mucosa was removed by sharp dissection. After washing with PBS containing 0.3\% Triton X-100 (PBST) for several days, with several changes of solution, musculatures were incubated in normal donkey serum (5\% in PBST) for 1 hour at room temperature. 
Tissues were incubated with antibodies diluted in PBST for at least 48 hours at $4{ }^{\circ} \mathrm{C}$. The tissues were washed with PBS, and incubated in secondary antibodies (Alexa Fluor-coupled donkey anti-IgG, 1:500 in PBST) for 1 hour at room temperature. After washing with PBS, specimens on glass slides were mounted with PermaFluor Aqueous Mounting Medium.

Double-labeled immunofluorescence images were examined using a Leica TCS-SP2 confocal microscope (Leica Microsystems, Germany) with excitation wavelengths of $488 \mathrm{~nm}$ and $543 \mathrm{~nm}$. Images were collected and measured using Leica Confocal Software (Leica Microsystems). Photoshop CS2 (Adobe Systems, USA) was used to compose the final plates.

For immunoelectron microscopy (Iino and Nojyo, 2006), the GI tracts of three guinea pigs were fixed with Zamboni's fixative plus $0.1 \%$ glutaraldehyde for 1 hour. The tissues were removed from the Sylgard dish and further immersed in Zamboni's fixative for 3 hours at room temperature. Tissues were then cut using a cryostat, at $12 \mu \mathrm{m}$, and mounted on poly-L-lysine coated slides. After washing with PBS, sections were incubated for 1 hour in 10\% normal goat serum, and reacted with anti-sGC $\beta 1$ (1:1000) for 24 hours at $4^{\circ} \mathrm{C}$. Sections were washed three times with PBS, and then reacted with biotinylated goat anti-rabbit IgG (1:200 with PBS, Vector, USA) for 2 hours. After washing with PBS, they were reacted with avidin-biotin-peroxidase complex (ABC kit, Vector) for 2 hours. The sections were incubated for several minutes with a solution containing $0.03 \%$ diaminobenzidine, $0.005 \% \mathrm{H} 2 \mathrm{O} 2$ in $0.1 \mathrm{M}$ Tris- $\mathrm{HCl}$, $\mathrm{pH}$ 7.6. After coloration in diaminobenzidine solution, specimens were post-fixed in $1 \% \mathrm{OsO} 4$ in $0.1 \mathrm{M}$ phosphate buffer, $\mathrm{pH} 7.4$ for 1 hour, block-stained with uranyl acetate, dehydrated in ethanol and embedded in epoxy resin (Epok 812, Oken, Japan). Ultrathin sections were examined using an H-7000 electron microscope (Hitachi, Japan).

For immunoblot analysis, the musculature of small intestines was homogenized in $20 \mathrm{mM}$ Tris-HCl (pH 7.5), 1 mM ethylenediaminetetraacetic acid (Nakalai, Japan) and $1 \mathrm{mM}$ phenyl methyl sulfonyl fluoride (Nakalai). The homogenates were centrifuged at $1000 \mathrm{xg}$ at $4{ }^{\circ} \mathrm{C}$ for 30

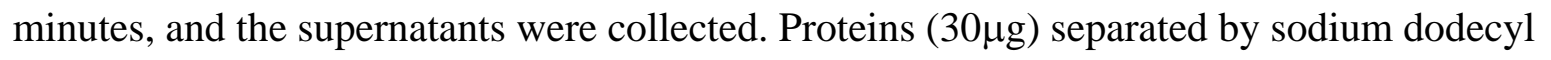
sulphate-polyacrylamide gel electrophoresis using a 7.5\% polyacrylamide gel were transferred to a polyvinylidene difluoride membrane (Immobilon-P, Millipore, USA). Membranes were blocked with 5\% fat-free dry milk in PBS containing 0.05\% Tween-20 and then incubated with anti-sGC $\beta 1$ (1:5000), anti-sGC $\alpha 1$ (1:4000), anti-c-Kit (1:1000) or anti-nNOS (1:20000) antibody solutions. Immune complexes were visualized using a chemiluminescence system (ECL Plus, Amersham Pharmacia Biotech, UK) with HRP-conjugated anti-IgG. Immunoblots using anti-sGC $\beta 1$, anti-sGC $\alpha 1$, anti-c-Kit and anti-nNOS antibodies demonstrated the presence of specific immunoreactive bands at approximately 68 kDa, 77kDa, $145 \mathrm{kDa}$ and 135/125 kDa, respectively (Fig. 1). 


\section{RESULTS}

1. Distribution of sGC $\beta 1$ immunoreactivity in the guinea pig GI tract (Table 1)

sGC $\beta 1$ immunoreactivity was mainly observed in the non-smooth muscle cells and neurons in the external muscle layers. Smooth muscle cells in the musculature showed no or weak immunoreactivity. To identify sGC $\beta 1$-immunopositive non-smooth muscle cells, we performed double immunohistochemistry using sGC $\beta 1$ and c-Kit antibodies, the latter of which is a marker of ICC in the GI tract (Burns et al., 1997; Rumessen and Vanderwinden, 2003; Iino and Horiguchi, 2006); the results showed that many sGC $\beta 1$-immunopositive cells had c-Kit immunoreactivity. We also observed c-Kit-negative sGC $\beta 1$-immunopositive cells. These cells, situated in or between the muscle layers, resembled fibroblasts or fibroblast-like cells (FLC) (Komuro et al., 1999; Rumessen and Vanderwinden, 2003). There were also c-Kit negative sGC $\beta 1$-immunopositive cells around capillaries that resembled pericytes based on their distribution and morphology (Shepro and Morel, 1993; Armulik et al., 2005). Smooth muscle cells in the muscularis mucosae and vasculature showed sGC $\beta 1$ immunoreactivity.

\section{Esophagus}

sGC $\beta 1$-immunopositive cells were scattered in the esophageal wall (Fig. 2). Using whole-mount preparations, we observed a small number of isolated c-Kit-immunopositive ICC that were also sGC $\beta 1$ immunopositive, with spindle-shaped cytoplasms, oriented along the striated muscle fibers. Most sGC $\beta 1$-immunopositive cells were c-Kit negative and were distributed along small vessels.

\section{Stomach}

In the gastric fundus (Fig. 3A), corpus (Fig. 3B) and pylorus (Fig. 3C), sGC $\beta 1$ immunoreactivity was clearly observed in almost all ICC-IM in the circular and longitudinal muscle layers. On whole-mount preparations, ICC-IM immunoreactive for c-Kit and sGC $\beta 1$ showed a characteristic bipolar shape with long, thin processes (Fig. 3G, 3H). These cells were oriented in parallel to the long axis of the muscle fibers in both layers. Ultrastructural observations revealed that sGC $\beta 1$-immunopositive cells corresponded to ICC-IM (Fig. 6A, 6B). These cells possessed oval nuclei and many mitochondria. They were closely associated with nerve bundles and made contacts with neighboring smooth muscle cells. ICC-MY in the gastric corpus and pylorus showed no immunoreactivity for sGC $\beta 1$. c-Kit-negative sGC $\beta 1$-immunopositive cells were observed in the muscle layers and myenteric layer. These cells showed bipolar or multipolar shape and resembled 
FLC (Fig. 3J). The inner fourth or fifth of the smooth muscle in the circular layer contained no or few ICC, and showed moderate sGC $\beta 1$ immunoreactivity. The enteric neurons in the myenteric ganglia and nerve fibers in the musculature showed sGC $\beta 1$ immunoreactivity.

To examine the structural relationship between sGC $\beta 1$-containing cells and nitrergic nerves, cryostat sections and whole-mounts of the gastric musculature were double labeled using anti-sGC $\beta 1$ and anti-nNOS antibodies. Transverse sections through the gastric wall showed that most nNOS-immunopositive nerve fibers were closely associated with sGC $\beta 1$-immunopositive cells (Fig. 3D-F). In the whole-mount preparations, sGC $\beta 1$-immunopositive ICC-IM were clearly observed to be oriented parallel to the long axis of the muscle fibers, with nNOS-immunopositive nerve fibers in both layers (Fig. 3I). The inner smooth muscle of the circular layer, in which there were moderately sGC $\beta 1$-immunopositive smooth muscle cells, contained many nNOS-immunopositive nerve fibers.

\section{Small intestine}

In the small intestine, sGC $\beta 1$-immunopositive cells were observed in the muscle layers and myenteric layer (Fig. 4A, 4B). Using double immunohistochemistry with anti-c-Kit and anti-sGC $\beta 1$ antibodies, ICC-DMP showed weak immunoreactivity for sGC $\beta 1$ (Fig. 4A, 4C). Using whole-mount preparations, the perinuclear areas of the ICC-DMP contained weak sGC $\beta 1$ immunoreactivity, whereas the processes of the ICC-DMP showed intense immunoreactivity (Fig. 4E). Immunoelectron microscopy confirmed these observations: the processes of ICC-DMP showed distinct sGC $\beta 1$ immunoreactivity (Fig. 6C), whereas the cell bodies had moderate immunoreactivity. These cells were characterized by having many mitochondria. They possessed caveolae in their cell membranes and formed gap junctions with each other or with smooth muscle cells of the outer circular layer. In the DMP layer, there was another type of sGC $\beta 1$-immunoreactive cells, which lacked c-Kit immunoreactivity (Fig. 4A, 4C). These sGC $\beta 1$-immunopositive cells had oval or round cell bodies with several short processes (Fig. 4E). By electron microscopy, intense sGC $\beta 1$-immunoreactive cells could be distinguished from ICC-DMP, being irregular in shape and having several thin processes extending in different directions (Fig. 6D). A well-developed rough endoplasmic reticulum could be seen within the cytoplasm of these cells. Caveolae were not observed. They were closely associated with nerve bundles and made small contacts with smooth muscle cells. From the shape of these cells and their ultrastructural features, we concluded that these non-ICC cells were FLC. In the DMP, many nNOS-immunoreactive nerve fibers were observed, and these were associated with sGC $\beta 1$-immunoreactive cells (Fig. 4B). Using whole-mount double immunohistochemistry, sGC $\beta 1$-immunoreactive cells were adjacent to 
nNOS-immunopositive fibers (Fig. 4F). Electron microscopy clearly showed that these sGC $\beta 1$-immunoreactive cells were associated with nerve fibers (Fig. 6C, 6D).

In the myenteric layer, there were two distinct types of cells: ICC-MY (c-Kit-immunopositive) and sGC $\beta 1$-immunoreactive (c-Kit-immunonegative) cells. Whole-mount observations revealed a sGC $\beta 1$-immunoreactive cell network and a c-Kit-immunoreactive ICC network in the myenteric layer (Fig. 4G). sGC $\beta 1$-immunoreactive cells had larger perinuclear regions than ICC, and several short processes with weak sGC $\beta 1$ immunoreactivity. Under an electron microscope, sGC $\beta 1$-immunoreactive cells showed fibroblast-like features, such as irregular cell shape, thin processes extending in different directions, well-developed rough endoplasmic reticulum and a lack of caveolae (Fig. 6E). On the other hand, ICC-MY, which were characterized by oval nuclei and numerous mitochondria, were sGC $\beta 1$-immunonegative (Fig. 6E).

There were many sGC $\beta 1$-immunopositive cells in the circular and longitudinal muscle layers that were immunonegative for c-Kit. These cells resembled fibroblasts or FLC (Fig. 6). These cells were also closely associated with nNOS-immunopositive nerve fibers (Fig. 4B).

\section{Large intestine}

In the cecum (Fig. 5A), almost all ICC-IM and ICC-MY showed distinct sGC $\beta 1$ immunoreactivity. ICC-IM in the circular and longitudinal muscle had typical morphology, namely a bipolar long slender form. In the myenteric layer, c-Kit-immunopositive multipolar cells (ICC-MY) showed sGC $\beta 1$ immunoreactivity. There were several c-Kit-immunonegative sGC $\beta 1$-immunopositive cells in the myenteric layer, as observed in other regions. The nerve fibers with nNOS immunoreactivity were associated with sGC $\beta 1$-immunopositive cells, both in the circular and longitudinal muscle layers (Fig. 5D).

In the proximal (Fig. 5B) and distal colon (Fig. 5C), sGC $\beta 1$ immunoreactivity was observed in all ICC-IM and most ICC-MY. In the circular and longitudinal muscle layers, typical ICC-IM with long slender processes showed intense sGC $\beta 1$ immunoreactivity. ICC-IM extended their processes along the major axis of smooth muscle cells (Fig. 5G). In the myenteric layer, ICC-MY with a multipolar shape showed intense sGC $\beta 1$ immunoreactivity; c-Kit-immunonegative cells with weak sGC $\beta 1$ immunoreactivity were also observed (Fig. 5I). The smooth muscle cells in the inner third of the circular layer showed higher immunoreactivity for sGC $\beta 1$ than the outer two thirds of the circular muscle. This area contained fewer ICC than the outer part of the circular muscle.

Using immunoelectron microscopy, intense sGC $\beta 1$ immunoreactivity was detected in ICC-IM distributed both in the circular and longitudinal muscle layers (Fig. 6G). These cells 
possessed oval nuclei with scant perinuclear cytoplasm in comparison with smooth muscle cells; they also contained many mitochondria. Around the myenteric ganglia, sGC $\beta 1$-immunopositive cells had long processes and many mitochondria (Fig. 6F, 6H). These characteristic features confirmed that the sGC $\beta 1$-immunopositive cells were colonic ICC-MY. There were weakly sGC $\beta 1$-immunopositive cells with fibroblast-like features as long thin processes. These cells lay scattered in the myenteric layer.

Double-immunofluorescence immunohistochemistry revealed that almost all sGC $\beta 1$-immunopositive cells in the muscle layer of the colon were situated adjacent to nNOS-immunopositive nerve fibers (Fig. 5E, 5F). Nerve fibers extended along both the cell bodies and processes of the sGC $\beta 1$-immunopositive cells (Fig. 5H). The inner third of the circular layer, which contained many nNOS-immunopositive nerve fibers, consisted of moderately sGC $\beta 1$-immunopositive smooth muscle cells, and was free from ICC-IM.

6. Distribution of sGC $\alpha 1$ immunoreactivity in the guinea pig GI tract

sGC $\alpha 1$ immunoreactivity showed almost the same distribution as sGC $\beta 1$ immunoreactivity in the gastric corpus (Fig. 7A), ileum (Fig. 7B) and proximal colon (Fig. 7C). ICC-IM in the corpus and colon expressed distinct sGC $\alpha 1$ immunoreactivity. ICC-DMP in the ileum showed weak sGC $\alpha 1$ immunoreactivity. Although ICC-MY in the colon displayed sGC $\alpha 1$ immunoreactivity, those in the corpus and ileum were free from sGC $\alpha 1$ immunoreactivity. ICC-SM in the colon had no immunoreactivity. c-Kit-negative sGC $\alpha 1$-immunopositive cells having FLC characteristics were observed in the musculature. Myenteric ganglia showed diffuse immunoreactivity. 


\section{DISCUSSION}

The results of our immunohistochemical investigations assign sGC $\beta 1$ expression precisely to ICC, FLC and neurons in the GI musculature of the guinea pig. Because sGC requires the coexpression of one $\alpha$ and one $\beta$ subunit for catalytic action (Koesling et al., 2004; Cary et al., 2006), it is important to detect both subunits in the same cells. We obtained almost the same distribution of sGC $\alpha 1$ immunoreactivity as sGC $\beta 1$ immunoreactivity. RT-PCR experiments showed that the musculature and isolated ICC-DMP of the murine small intestine expressed mRNAs for sGC $\alpha 1$ and sGC $\beta 1$ (Chen et al., 2007). Deletion of the $\beta 1$ subunit gene results in a loss of not only $\beta 1$ subunit protein, but also $\alpha 1$ and $\alpha 2$ subunits, because of the instability of $\alpha$ subunits when expressed without the dimerizing partner $\beta 1$ subunit (Friebe et al., 2007). Therefore, we considerer that the expression analysis of the sGC $\beta 1$ subunit performed in this study indicates the functional distribution of sGC and that cells containing sGC $\beta 1$ are targets of NO signaling.

This study demonstrates, for the first time, the presence of sGC in numerous ICC using double immunohistochemistry for sGC and the ICC marker c-Kit (Burns et al., 1997; Rumessen and Vanderwinden, 2003; Iino and Horiguchi, 2006). Using whole-mount preparations, the morphology and sGC $\beta 1$ expression of ICC can clearly be observed. Salmhofer et al. (2001) showed sGC in flattened cells around the myenteric ganglia and in specialized cells in the DMP in the rat small intestine. Using double immunohistochemistry, they also showed that half of the sGC-immunopositive cells in the DMP were c-Kit immunopositive. Our study, using double immunohistochemistry and electron microscopy, clarified that ICC-DMP in the guinea pig small intestine showed sGC $\beta 1$ immunoreactivity. We could also distinguish sGC $\beta 1$-immunopositive FLC from ICC in the DMP and myenteric layers, and confirmed the previous findings by Salmhofer et al. (2001). We conclude that there are two types of sGC $\beta 1$-immunopositive cells, namely ICC and FLC, in the GI tract.

NO is produced by NOS and diffuses freely across cell membranes to reach its receptor, sGC. Because NO has a very short half-life (Lancaster Jr, 1997), sGC-containing cells are necessarily situated near NO synthesizing structures. Using double immunohistochemistry, we clearly observed that almost all sGC $\beta 1$-immunopositive cells were found in close proximity to nNOS-immunopositive nerves. Under the electron microscope, many sGC $\beta 1$-immunopositive cells were seen to be located near the nerve fibers or cell bodies. These relationships suggest that sGC $\beta 1$-containing cells in the GI musculature receive NO signaling predominantly from nNOS-containing enteric nerves. Nitrergic nerve stimulation using electrical field stimulation results in inhibitory junctional potential and relaxation of smooth muscle in the GI tract, and these 
responses are thought to be mediated through ICC-IM (Ward and Sanders, 2001; Ward et al., 2004). The role of ICC-IM in neurotransmission appears to be dependent upon the close anatomical relationship between nerve terminals and ICC (Komuro et al., 1999; Wang et al., 1999, 2000; Ward et al., 2000). Physiological studies in mice lacking ICC-IM have shown that ICC-IM mediate post-junctional responses to enteric excitatory and inhibitory neurotransmission (Burns et al., 1996; Ward et al., 2000; Beckett et al., 2002). Our study demonstrated that ICC-IM were innervated by NOS-containing nerve terminals and contained the NO-sensitive molecule sGC $\beta 1$ in their soma. Marked expression of sGC $\beta 1$ in ICC-IM confirms the functional implications for NO mediated neurotransmission in the GI musculature.

ICC-MY in the stomach and small intestine, and ICC-SM in the colon, are known to generate slow waves (Sanders, 1996; Rumessen and Vanderwinden, 2003). These cells showed no immunoreactivity for sGC. There are several functional reports regarding cGMP and slow waves. In the canine antrum (Burke et al., 1996) and ileum (Cayabyab et al., 1997), and the guinea pig antrum (Kim et al., 2003) and proximal colon (Watson et al., 1996), slow waves were influenced by NO/cGMP signaling cascades. Using isolated ICC-MY from the murine small intestine, cGMP produced from sGC has been shown to regulate the slow wave frequency underlying pacemaker function (Koh et al., 2000). In a functional immunohistochemical study, ICC-SM in the canine colon responded to NO stimulation with an increase in cGMP level (Shuttleworth et al., 1993). Although there is a discrepancy between our immunohistochemical findings and previous functional findings in ICC-MY and ICC-SM, there remains the possibility that sGC is present in ICC-MY and ICC-SM, because immunohistochemical methods have limited detection sensitivity. Further study, using RT-PCR, is required to clarify the existence of sGC in these ICC. On the other hand, ICC-MY in guinea pig colon showed distinct sGC immunoreactivity. Although there have been few findings concerning colonic ICC-MY and NO signaling, Keef et al. (1997) suggested that electrical activity from ICC-MY in the canine colon was suppressed by NO.

There were numerous FLC expressing various intensities of sGC immunoreactivity in the musculature. The ultrastructural features of these cells were a well-developed rough endoplasmic reticulum and a lack of basal lamina and caveolae. These characteristics suggested that the sGC-immunopositive cells lacking c-Kit immunoreactivity were FLC (or fibroblasts) (Komuro et al., 1999; Horiguchi and Komuro, 2000). In the myenteric layer, sGC $\beta 1$-immunopositive FLC and ICC-MY were joined to each other and made their own networks independently. In the DMP layer, both FLC and ICC-DMP contained sGC $\beta 1$ immunoreactivity and were adjacent to nerve fibers. The FLC are likely to be involved in intestinal motility, because of the existence of gap junction or gap junction-like structures between FLC and smooth muscle cells (Horiguchi and Komuro, 2000). Rumessen and Vanderwinden (2003) named fibroblasts or FLC in the GI musculature non-Cajal 
interstitial cells (NCIC). NCIC are known to associate with nerve fibers and express one of the $\mathrm{K}^{+}$ channels, SK3 (Vanderwinden et al., 2002; Fujita et al., 2003). Although the role of NCIC remains essentially unknown, these features suggest a role for NCIC in the control of excitability of the GI musculature (Rumessen and Vanderwinden, 2003). Further study will confirm the expression of sGC and SK3 in FLC or NCIC. The expression of the functional molecule sGC in FLC, and the relationships between FLC and nerve fibers, suggest that FLC in the musculature are regulated by NO/cGMP signaling and modulate smooth muscle function.

In contrast to the marked expression of sGC $\beta 1$ in ICC and FLC, smooth muscle cells in the musculature showed weak or no sGC $\beta 1$ immunoreactivity. The appropriateness of this immunohistochemical study was shown by the fact that smooth muscle cells in the muscularis mucosae and vessels had distinct immunoreactivity for sGC $\beta 1$. Smooth muscle cells in the inner part of musculature of the stomach and colon showed weak but distinct sGC $\beta 1$ immunoreactivity. The muscular areas showing sGC $\beta 1$ immunoreactivity lacked ICC-IM (Seki et al., 1998), and contained nNOS-immunopositive nerve fibers. We previously reported that the smooth muscle cells of these areas lacked the muscarinic receptor M2 subtype (Iino and Nojyo, 2006). These findings suggest that the smooth muscle cells of the inner parts of the musculature are functionally different from the smooth muscle cells in the outer part in that they are prominently innervated by inhibitory nitrergic nerves, and directly receive NO signals as vascular smooth muscle cells (Hofmann et al., 2000).

NO signaling regulates the GI functions through sGC. sGC stimulation by NO results in the production of second messenger, cGMP, which mediates its effects via cGMP-dependent kinases, cGMP-regulated phosphodiesterases and cyclic nucleotide-gated channels (Hofmann et al., 2000). The immunohistochemical localization of cGMP has been studied to determine potential physiological sites of action of NO in the GI musculature. cGMP productions in ICC and FLC of guinea pig intestine were reported in response to stimulation with NO donor, sodium nitroprusside (SNP) (Young et al., 1993). Exposure to SNP or nerve stimulation of canine colonic muscles caused cGMP production in ICC as well as neurons and smooth muscle cells (Shuttleworth et al., 1993). Functional studies showed that the electrical and mechanical effects of NO in the canine colon and guinea pig cecum were largely due to cGMP synthesis by sGC (Ward et al., 1992; Young et al., 1996; Franck et al., 1997). cGMP-dependent kinase type I was detected diffusely in the GI musculature (Huber et al., 1998; Ny et al., 2000) and in the ICC-DMP and smooth muscle cells in the rat small intestine (Salmhofer et al., 2001). We need to further investigate the mechanisms underlying cGMP synthesis and the roles of cGMP-dependent kinases, cGMP-regulated phosphodiesterases and cyclic nucleotide-gated channels in the GI musculature, and have preliminary data regarding the predominant expression of cGMP, cGMP-dependent kinase I and 
phosphodiesterase 5 in the guinea pig ICC (unpublished data). Our finding of an NO-receptive mechanism suggests that ICC preferentially use NO/cGMP signaling and regulate the GI musculature by a cGMP-dependent mechanism.

In conclusion, this study presents an entirely new range of cell types expressing the NO-sensitive molecule sGC in the guinea pig GI musculature. Significant expression was localized to ICC with particularly high intensity in the FLC, neurons and vascular smooth muscle cells. Both ICC and FLC were closely associated with nNOS-containing nerves. Significant expression of NO-sensitive GC in ICC and the morphological relationship between ICC and nitrergic nerves suggest that ICC are primary targets for nitrergic neurotransmission in the GI musculature. The identification of FLC that also contain SGC immunoreactivity and associate with nitrergic nerves suggests a definite role for NO signaling in the musculature. 


\section{REFERENCES}

Armulik A, Abramsson A, Betsholtz C (2005) Endothelial/pericyte interactions. Circ Res 97:512-523.

Beckett EA, Horiguchi K, Khoyi M, Sanders KM, Ward SM (2002) Loss of enteric motor neurotransmission in the gastric fundus of $S l / S I^{d}$ mice. J Physiol (Lond) 543:871-887.

Burke EP, Gerthoffer WT, Sanders KM, Publicover NG (1996) Wortmannin inhibits contraction without altering electrical activity in canine gastric smooth muscle. Am J Physiol Cell Physiol 270:C1405-C1412.

Burns AJ, Herbert TM, Ward SM, Sanders KM (1997) Interstitial cells of Cajal in the guinea-pig gastrointestinal tract as revealed by c-Kit immunohistochemistry. Cell Tissue Res 290:11-20.

Burns AJ, Lomax AE, Torihashi S, Sanders KM, Ward SM (1996) Interstitial cells of Cajal mediate inhibitory neurotransmission in the stomach. Proc Natl Acad Sci USA 93:12008-12013.

Cary SP, Winger JA, Derbyshire ER, Marletta MA (2006) Nitric oxide signaling: no longer simply on or off. Trends Biochem Sci 31:231-239.

Cayabyab FS, Jimenez M, Vergara P, deBruin H, Daniel EE (1997) Influence of nitric oxide and vasoactive intestinal peptide on the spontaneous and triggered electrical and mechanical activities of the canine ileum. Can J Physiol Pharmacol 75:383-397.

Chen H, Redelman D, Ro S, Ward SM, Ordog T, Sanders KM (2007) Selective labeling and isolation of functional classes of interstitial cells of Cajal of human and murine small intestine. Am J Physiol Cell Physiol 292:C497-C507.

De Man JG, De Winter BY, Herman AG, Pelckmans PA (2007) Study on the cyclic GMP-dependency of relaxations to endogenous and exogenous nitric oxide in the mouse gastrointestinal tract. Br J Pharmacol 150:88-96.

Dijkstra G, van Goor H, Jansen PL, Moshage H (2004) Targeting nitric oxide in the gastrointestinal tract. Curr Opin Investig Drugs 5:529-536.

Epperson A, Hatton WJ, Callaghan B, Doherty P, Walker RL, Sanders KM, Ward SM, Horowitz B (2000) Molecular markers expressed in cultured and freshly isolated interstitial cells of Cajal. Am J Physiol Cell Physiol 279:C529-C539.

Franck H, Sweeney KM, Sanders KM, Shuttleworth CW (1997) Effects of a novel guanylate cyclase inhibitor on nitric oxide-dependent inhibitory neurotransmission in canine proximal colon. Br J Pharmacol 122:1223-1229.

Friebe A, Mergia E, Dangel O, Lange A, Koesling D (2007) Fatal gastrointestinal obstruction and 
hypertension in mice lacking nitric oxide-sensitive guanylyl cyclase. Proc Natl Acad Sci U S A 104:7699-7704.

Fujita A, Takeuchi T, Jun H, Hata F (2003) Localization of $\mathrm{Ca}^{2+}$-activated $\mathrm{K}^{+}$channel, SK3, in fibroblast-like cells forming gap junctions with smooth muscle cells in the mouse small intestine. J Pharmacol Sci 92:35-42.

Herbison AE, Simonian SX, Norris PJ, Emson PC (1996) Relationship of neuronal nitric oxide synthase immunoreactivity to GnRH neurons in the ovariectomized and intact female rat. J Neuroendocrinol 8:73-82.

Hofmann F, Ammendola A, Schlossmann J (2000) Rising behind NO: cGMP-dependent protein kinases. J Cell Sci 113:1671-1676.

Horiguchi K, Komuro T (2000) Ultrastructural observations of fibroblast-like cells forming gap junctions in the W/W $\mathrm{W}^{\mathrm{v}}$ mouse small intestine. J Auton Nerv Syst 80:142-147.

Huber A, Trudrung P, Storr M, Franck H, Schusdziarra V, Ruth P, Allescher HD (1998) Protein kinase $\mathrm{G}$ expression in the small intestine and functional importance for smooth muscle relaxation. Am J Physiol Gastrointest Liver Physiol 275:G629-G637.

Iino S, Horiguchi K (2006) Interstitial cells of cajal are involved in neurotransmission in the gastrointestinal tract. Acta Histochem Cytochem 39:145-153.

Iino S, Nojyo Y (2006) Muscarinic M2 acetylcholine receptor distribution in the guinea-pig gastrointestinal tract. Neuroscience 138:549-559.

Keef KD, Murray DC, Sanders KM, Smith TK (1997) Basal release of nitric oxide induces an oscillatory motor pattern in canine colon. J Physiol (Lond) 499:773-786.

Kim T, La J, Lee J, Yang I (2003) Effects of nitric oxide on slow waves and spontaneous contraction of guinea pig gastric antral circular muscle. J Pharmacol Sci 92:337-347.

Koesling D, Russwurm M, Mergia E, Mullershausen F, Friebe A (2004) Nitric oxide-sensitive guanylyl cyclase: structure and regulation. Neurochem Int 45:813-819.

Koh SD, Kim TW, Jun JY, Glasgow NJ, Ward SM, Sanders KM (2000) Regulation of pacemaker currents in interstitial cells of Cajal from murine small intestine by cyclic nucleotides. J Physiol (Lond) 527 :149-162.

Komuro T, Seki K, Horiguchi K (1999) Ultrastructural characterization of the interstitial cells of Cajal. Arch Histol Cytol 62:295-316.

Krumenacker JS, Hanafy KA, Murad F (2004) Regulation of nitric oxide and soluble guanylyl cyclase. Brain Res Bull 62:505-515.

Lancaster Jr JR (1997) A tutorial on the diffusibility and reactivity of free nitric oxide. Nitric Oxide 1:18-30.

Mergia E, Friebe A, Dangel O, Russwurm M, Koesling D (2006) Spare guanylyl cyclase NO 
receptors ensure high NO sensitivity in the vascular system. J Clin Invest 116:1731-1737.

Ny L, Pfeifer A, Aszodi A, Ahmad M, Alm P, Hedlund P, Fassler R, Andersson KE (2000) Impaired relaxation of stomach smooth muscle in mice lacking cyclic GMP-dependent protein kinase I. Br J Pharmacol 129:395-401.

Pyriochou A, Papapetropoulos A (2005) Soluble guanylyl cyclase: more secrets revealed. Cell Signal 17:407-413.

Rumessen JJ, Vanderwinden JM (2003) Interstitial cells in the musculature of the gastrointestinal tract: Cajal and beyond. Int Rev Cytol 229:115-208.

Salmhofer H, Neuhuber WL, Ruth P, Huber A, Russwurm M, Allescher HD (2001) Pivotal role of the interstitial cells of Cajal in the nitric oxide signaling pathway of rat small intestine. Morphological evidence. Cell Tissue Res 305:331-340.

Sanders KM (1996) A case for interstitial cells of Cajal as pacemakers and mediators of neurotransmission in the gastrointestinal tract. Gastroenterology 111:492-515.

Seki K, Zhou DS, Komuro T (1998) Immunohistochemical study of the c-kit expressing cells and connexin 43 in the guinea-pig digestive tract. J Auton Nerv Syst 68:182-187.

Shepro D, Morel NM (1993) Pericyte physiology. FASEB J 7:1031-1038.

Shuttleworth CW, Xue C, Ward SM, de Vente J, Sanders KM (1993) Immunohistochemical localization of 3',5'-cyclic guanosine monophosphate in the canine proximal colon: responses to nitric oxide and electrical stimulation of enteric inhibitory neurons. Neuroscience 56:513-522.

Toda N, Herman AG (2005) Gastrointestinal function regulation by nitrergic efferent nerves. Pharmacol Rev 57:315-338.

Van Geldre LA, Lefebvre RA (2004) Interaction of NO and VIP in gastrointestinal smooth muscle relaxation. Current Pharmaceutical Design 10:2483-2497.

Vanderwinden JM, Rumessen JJ, De Kerchove D'Exaerde Jr A, Gillard K, Panthier JJ, Laet MH, Schiffmann SN (2002) Kit-negative fibroblast-like cells expressing SK3, a $\mathrm{Ca}^{2+}$-activated $\mathrm{K}^{+}$channel, in the gut musculature in health and disease. Cell Tissue Res 310:349-358.

Vannucchi MG (1999) Receptors in interstitial cells of Cajal: identification and possible physiological roles. Microsc Res Tech 47:325-335.

Wang XY, Sanders KM, Ward SM (1999) Intimate relationship between interstitial cells of Cajal and enteric nerves in the guinea-pig small intestine. Cell Tissue Res 295:247-256.

Wang XY, Sanders KM, Ward SM (2000) Relationship between interstitial cells of Cajal and enteric motor neurons in the murine proximal colon. Cell Tissue Res 302:331-342.

Ward SM, Beckett EA, Wang X, Baker F, Khoyi M, Sanders KM (2000) Interstitial cells of Cajal mediate cholinergic neurotransmission from enteric motor neurons. J Neurosci 
20:1393-1403.

Ward SM, Dalziel HH, Bradley ME, Buxton IL, Keef K, Westfall DP, Sanders KM (1992) Involvement of cyclic GMP in non-adrenergic, non-cholinergic inhibitory neurotransmission in dog proximal colon. Br J Pharmacol 107:1075-1082.

Ward SM, Morris G, Reese L, Wang XY, Sanders KM (1998) Interstitial cells of Cajal mediate enteric inhibitory neurotransmission in the lower esophageal and pyloric sphincters. Gastroenterology 115:314-329.

Ward SM, Sanders KM (2001) Interstitial cells of Cajal: primary targets of enteric motor innervation. Anat Rec 262:125-135.

Ward SM, Sanders KM, Hirst GDS (2004) Role of interstitial cells of Cajal in neural control of gastrointestinal smooth muscles. Neurogastroenterol Motil 16 Suppl 1:112-117.

Watson MJ, Bywater RA, Taylor GS, Lang RJ (1996) Effects of nitric oxide (NO) and NO donors on the membrane conductance of circular smooth muscle cells of the guinea-pig proximal colon. Br J Pharmacol 118:1605-1614.

Young HM, Ciampoli D, Johnson PJ, Stebbing MJ (1996) Inhibitory transmission to the longitudinal muscle of the mouse caecum is mediated largely by nitric oxide acting via soluble guanylyl cyclase. J Auton Nerv Syst 61:103-108.

Young HM, McConalogue K, Furness JB, De Vente J (1993) Nitric oxide targets in the guinea-pig intestine identified by induction of cyclic GMP immunoreactivity. Neuroscience 55:583-596. 


\section{FIGURE LEGENDS}

Fig. 1 Immunoblot analysis of the guinea pig gastrointestinal musculature Immunoblots using anti-sGC $\beta 1$ (lane 1), anti-sGC $\alpha 1$ (lane 2), anti-c-Kit (lane 3) and anti-nNOS (lane 4) antibodies demonstrate the presence of specific immunoreactive bands at approximately 68 kDa, $77 \mathrm{kDa}, 145 \mathrm{kDa}$ and 135/125 kDa, respectively. Molecular markers (kDa) are shown on the left.

Fig. 2 Distribution of sGC $\beta 1$ immunoreactivity in the guinea pig esophagus A: Cryostat section of the esophagus. In the circular (CM) and longitudinal (LM) muscle layers, there are many sGC $\beta 1$-immunopositive cells (green, arrowheads) and a small number of ICC (c-Kit immunopositive, red). ICC labeled with c-Kit antibody show sGC $\beta 1$ immunoreactivity (arrow). In the submucosa (SM), sGC $\beta 1$ immunopositive vasculatures (V) are observed. B: On the whole-mount preparation, c-Kit-immunopositive (red) ICC are observed with a bipolar spindle shape (arrow) and intense sGC $\beta 1$ immunoreactivity (green). c-Kit-immunonegative sGC $\beta 1$-immunopositive cells (arrowhead) are also observed. Bars: $50 \mu \mathrm{m}$

Fig. 3 Distribution of sGC $\beta 1$ immunoreactivity in the guinea pig stomach A-C: Cryostat sections of the gastric fundus (A), corpus (B) and pylorus (C) immunostained with anti-sGC $\beta 1$ (green) and anti-c-Kit (red) antibodies. ICC-IM in the circular layer show intense sGC $\beta 1$ immunoreactivity (arrows), whereas ICC-MY in the myenteric layer have no sGC $\beta 1$ immunoreactivity (arrowheads). Myenteric ganglia (G) show diffuse sGC $\beta 1$ immunoreactivity. Smooth muscle of the muscularis mucosae (MM) and vasculatures (V) show high sGC $\beta 1$ immunoreactivity. CM and LM show circular and longitudinal muscle, respectively. The inner parts of the circular muscle show weak sGC $\beta 1$ immunoreactivity (asterisks). D-F: Cryostat sections of the gastric fundus (D), corpus (E) and pylorus (F) immunostained with anti-sGCß1 (green) and anti-nNOS (red) antibodies. Most sGC $\beta 1$-immunopositive structures are adjacent to nNOS-immunopositive nerve fibers (arrows). Inner parts of the circular layer (asterisks) with weak sGC $\beta 1$ immunoreactivity contain many nNOS-immunopositive nerve fibers. GHJ: Whole-mount preparations of the gastric fundus $(\mathrm{G})$ and corpus $(\mathrm{H}, \mathrm{J})$ immunostained with anti-sGC $\beta 1$ (green) and anti-c-Kit (red) antibodies. ICC-IM (G, H) show bipolar shape with long, slender processes, and have distinct sGC $\beta 1$ immunoreactivity. ICC-MY (J) in the myenteric layer have no sGC $\beta 1$ immunoreactivity, whereas FLC show weak sGC $\beta 1$ immunoreactivity (arrowheads). I: Whole-mount preparation of the gastric fundus immunostained with anti-sGC $\beta 1$ (green) and 
anti-nNOS (red) antibodies. ICC-IM with sGC $\beta 1$ immunoreactivity are closely apposed to nNOS-immunopositive nerve terminals (arrows). Bars: $50 \mu \mathrm{m}$

Fig. 4 Distribution of sGC $\beta 1$ immunoreactivity in the guinea pig small intestine ACD: Cryostat sections using anti-sGC $\beta 1$ (green) and anti-c-Kit (red) antibodies. In the DMP layer (A, C), ICC-DMP (c-Kit immunopositive, arrows) show weak sGC $\beta 1$-immunoreactivity and c-Kit-immunonegative cells show intense sGC $\beta 1$ immunoreactivity (arrowheads). In the myenteric layer (D), there are two types of different immunoreactivity for c-Kit antibody (ICC-MY, arrows) and sGC $\beta 1$ antibody (arrowheads). Neurons in the myenteric ganglia (G) show distinct sGC $\beta 1$ immunoreactivity. CM and LM show circular and longitudinal muscle, respectively. B: Cryostat sections using the anti-sGC $\beta 1$ (green) and anti-nNOS (red) antibodies. sGC $\beta 1$-immunopositive cells are associated with nNOS-immunopositive nerves (arrows). E: Whole-mount preparation of the DMP layer using anti-sGC $\beta 1$ (green) and anti-c-Kit (red) antibodies. c-Kit immunopositive ICC (arrows) are characterized by their long, slender processes. These processes show intense sGC $\beta 1$ immunoreactivity, whereas cell bodies of ICC have weak sGC $\beta 1$ immunoreactivity. There are also c-Kit-immunonegative sGC $\beta 1$-immunopositive cells (asterisks). F: Whole-mount preparation of the DMP layer using anti-sGC $\beta 1$ (green) and anti-nNOS (red) antibodies. There are numerous nNOS-immunopositive nerve terminals associated with sGC $\beta 1$-immunopositive cells (asterisks). G: Whole-mount preparation of the myenteric layer using anti-sGC $\beta 1$ (green) and anti-c-Kit (red) antibodies. ICC-MY (red, arrows) are observed as cellular network. There are numerous sGC $\beta 1$-immunopositive cells (asterisks) that show wide cell bodies and short processes. Bars: 50 $\mu \mathrm{m}(\mathrm{AB}), 20 \mu \mathrm{m}(\mathrm{C}-\mathrm{G})$

Fig. 5 Distribution of sGC $\beta 1$ immunoreactivity in the guinea pig large intestine A-C: Cryostat sections of the cecum (A), proximal colon (B) and distal colon (C) immunostained with anti-sGC $\beta 1$ (green) and anti-c-Kit (red) antibodies. ICC-IM (arrows) both in the circular (CM) and longitudinal (LM) layers, and ICC-MY (arrowheads) in the myenteric layer, show intense sGC $\beta 1$ immunoreactivity. ICC-SM along the circular layer show no sGC $\beta 1$ immunoreactivity. Myenteric ganglia (G) show intense sGC $\beta 1$ immunoreactivity. The inner part of the circular muscle in the proximal colon shows weak sGC $\beta 1$ immunoreactivity (asterisks). D-F: Cryostat sections of the cecum (D), proximal colon (E) and distal colon (F) immunostained with anti-sGC $\beta 1$ (green) and anti-nNOS (red) antibodies. Most sGC $\beta 1$-immunopositive structures are adjacent to nNOS-immunopositive nerve fibers (arrows). The inner part of the circular layer (asterisks) with 
weak sGC $\beta 1$ immunoreactivity contains nNOS-immunopositive nerve fibers. GH: Whole-mount preparations of the circular layer of proximal colon. ICC-IM (G) show bipolar shape with long, slender processes and have distinct c-Kit (red) and sGC $\beta 1$ (green) immunoreactivities. ICC-IM (H) are closely apposed to nNOS-immunopositive nerve terminals (red, arrows). I: ICC-MY (arrows) in the distal colon have distinct sGC $\beta 1$ immunoreactivity, and FLC (asterisks) show weak sGC $\beta 1$ immunoreactivity. Bars: $50 \mu \mathrm{m}$ (A-F, I), $20 \mu \mathrm{m}(\mathrm{G}, \mathrm{H})$

Fig. 6 Electron microscopic demonstrations of sGC $\beta 1$ immunoreactivity in the guinea pig gastrointestinal tract

AB: Circular muscle layer of gastric antrum. ICC-IM (ICC) are sGC $\beta 1$ immunopositive, are closely associated with nerve bundles $(\mathrm{N})$ and made gap junction-like contact with smooth muscle cell (arrow). Some nerve fibers contain distinct sGC $\beta 1$ immunoreactivity. CD: Deep muscular plexus layer of small intestine. ICC-DMP (ICC) and their processes (asterisks) show moderate to high immunoreactivity. Nerve bundles $(\mathrm{N})$ are located in close vicinity to them. An arrow indicates a gap junction between ICC-DMP. A fibroblast-like cell (FLC) shows intense immunoreactivity in this region. They are also closely associated with nerve bundles $(\mathrm{N})$ and formed small contacts with smooth muscle cells (arrowhead). E: Myenteric region of the small intestine. Immunopositive FLC (FLC) and immunonegative ICC-MY (ICC) are situated near the myenteric ganglion (Ggl). Cp indicates a capillary. F: Myenteric region of proximal colon. Immunopositive ICC-MY (ICC) and immunonegative FLC (FLC) lie within the connective tissue space between the myenteric ganglion (Ggl) and circular muscle layer. G: Circular muscle layer of distal colon. ICC-IM (ICC) show intense immunoreactivity and are associated with nerve bundles $(\mathrm{N})$. H: Myenteric region of distal colon. Immunopositive ICC-MY (ICC) surround the myenteric ganglion (Ggl). Bars: $1 \mu \mathrm{m}$ (A-E, G, $\mathrm{H}), 5 \mu \mathrm{m}(\mathrm{F})$

Fig. 7 Distribution of sGC $\alpha 1$ immunoreactivity in the guinea pig gastrointestinal tract Cryostat sections of the gastric corpus (A), ileum (B) and proximal colon (C) immunostained with anti-sGC $\alpha 1$ (green) and anti-c-Kit (red) antibodies. ICC-IM (arrows) in the corpus and colon, ICC-DMP (arrows) in the ileum and ICC-MY (arrowheads) in the colon show intense sGC $\alpha 1$ immunoreactivity. ICC-MY (arrowheads) in the corpus and ileum and ICC-SM in the colon show no sGC $\alpha 1$ immunoreactivity. Myenteric ganglia (G) show diffuse sGC $\alpha 1$ immunoreactivity. CM and LM show circular and longitudinal muscle, respectively. Bars: $50 \mu \mathrm{m}$ 
Table 1. sGC $\beta 1$ immunoreactivity in the musculature of the guinea pig gastrointestinal tract ++ shows intense immunoreactivity, + shows weak immunoreactivity and - shows no immunoreactivity.

\begin{tabular}{|l|c|c|c|c|}
\hline & $\begin{array}{c}\text { Interstitial cells of } \\
\text { Cajal (ICC) }\end{array}$ & $\begin{array}{c}\text { Fibroblast-like } \\
\text { cells (FLC) }\end{array}$ & $\begin{array}{c}\text { Smooth muscle } \\
\text { cells in the } \\
\text { external muscle }\end{array}$ & $\begin{array}{c}\text { Smooth muscle } \\
\text { cells in the } \\
\text { muscularis } \\
\text { mucosae }\end{array}$ \\
\hline Esophagus & ++ & ++ & - \\
\hline Stomach & $\begin{array}{c}++(\mathrm{IM}) \\
-(\mathrm{MY})\end{array}$ & ++ & ++ \\
\hline Small intestine & $\begin{array}{c}+(\mathrm{DMP}) \\
-(\mathrm{MY})\end{array}$ & ++ & - & + \\
\hline Cecum & $++(\mathrm{IM})$ & + & - & + \\
\hline Colon & $+(\mathrm{MY})$ & $+(\mathrm{IM})$ & + & + \\
\hline
\end{tabular}




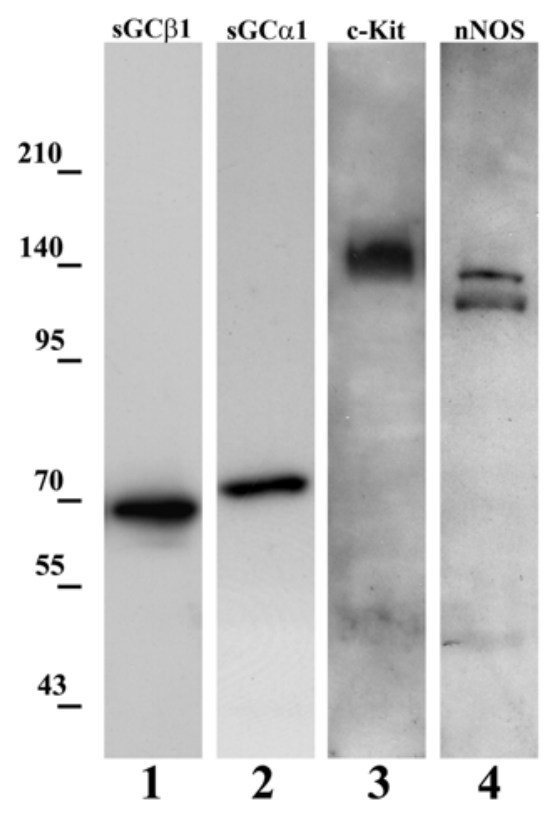

(Fig. 1)

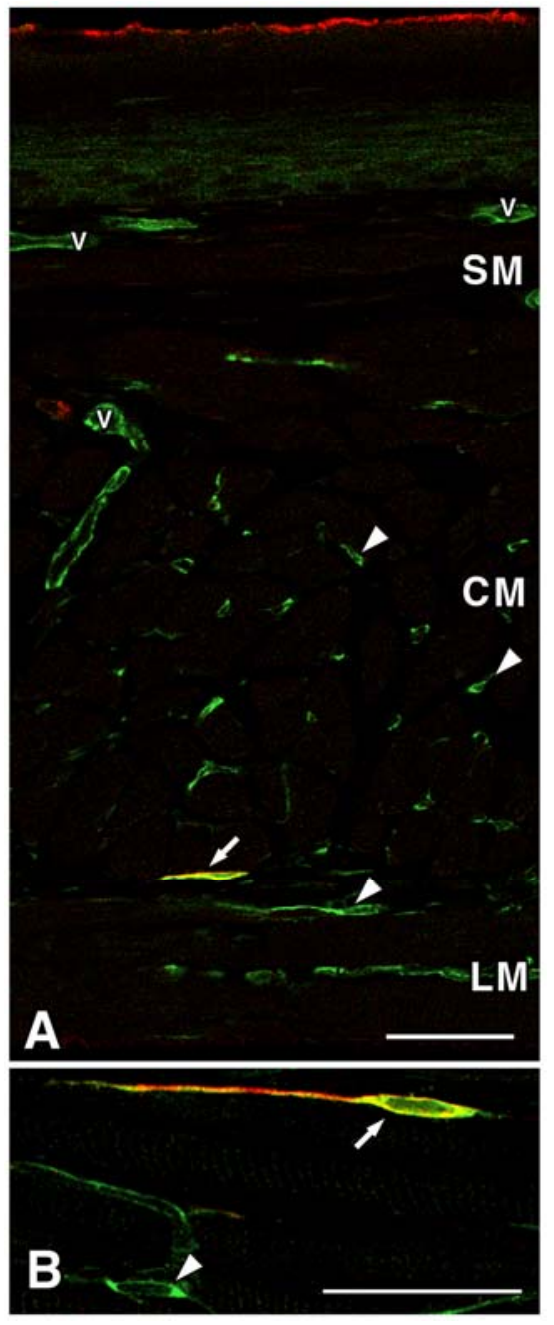

(Fig. 2) 

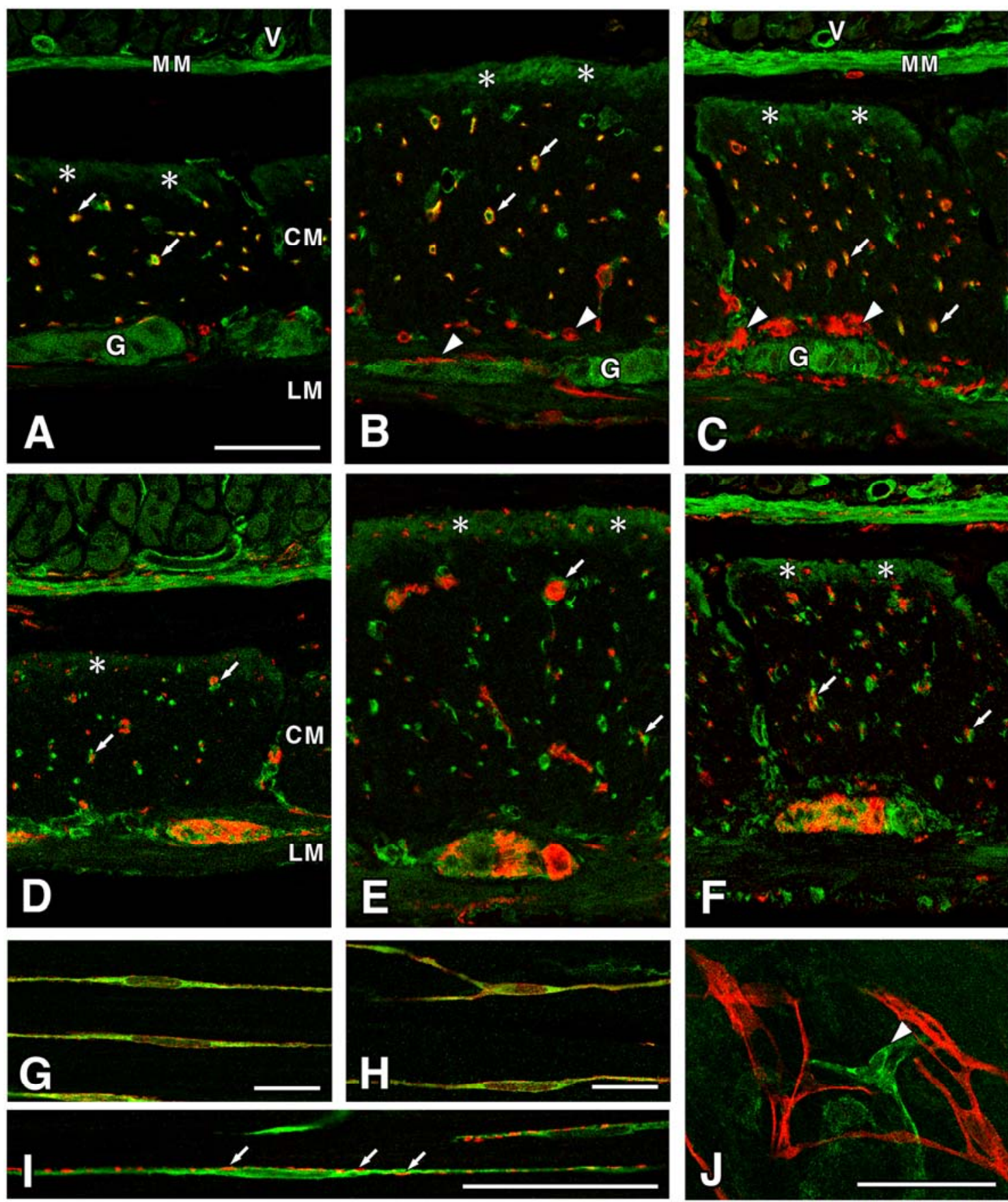

(Fig. 3) 

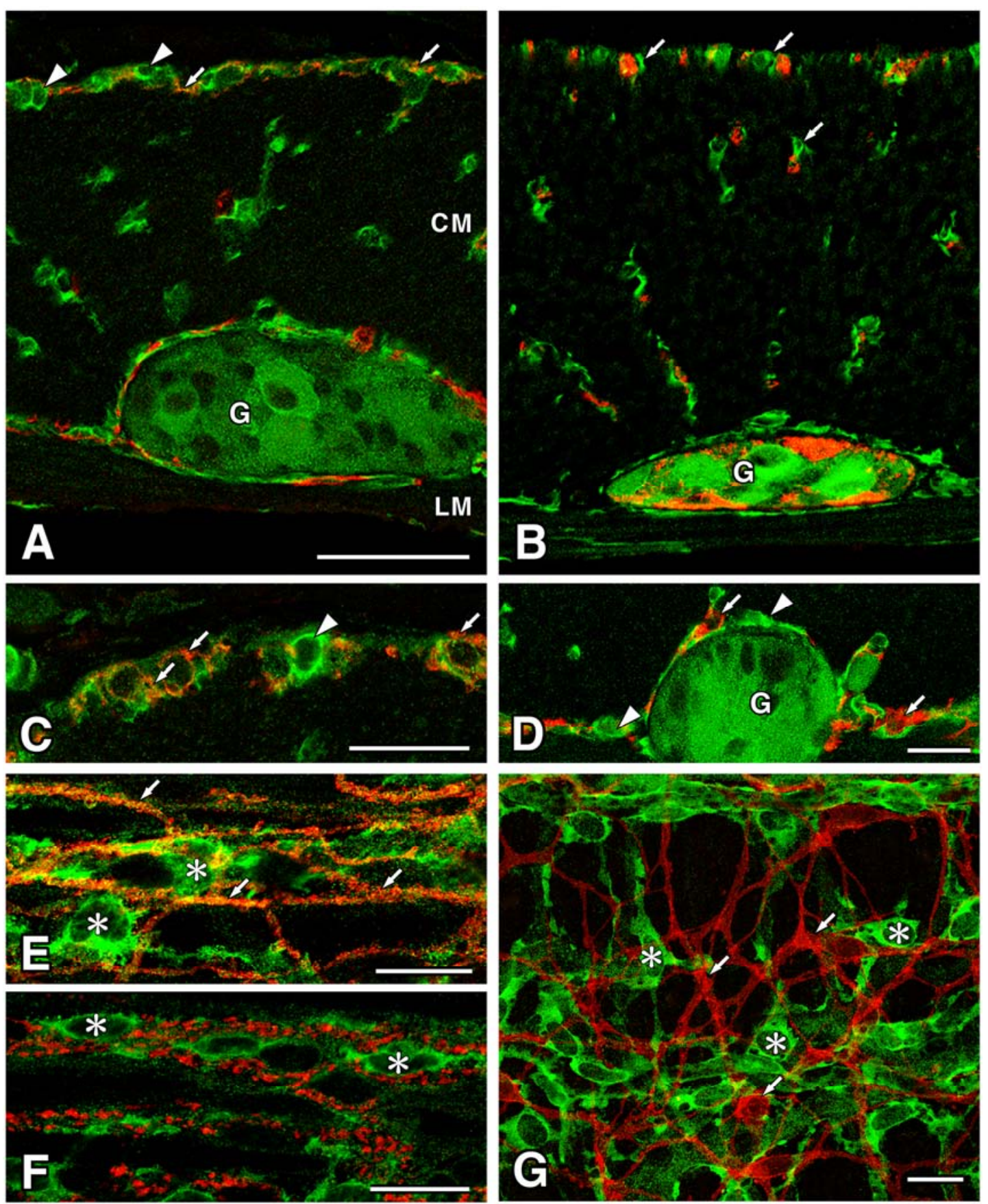

(Fig. 4) 

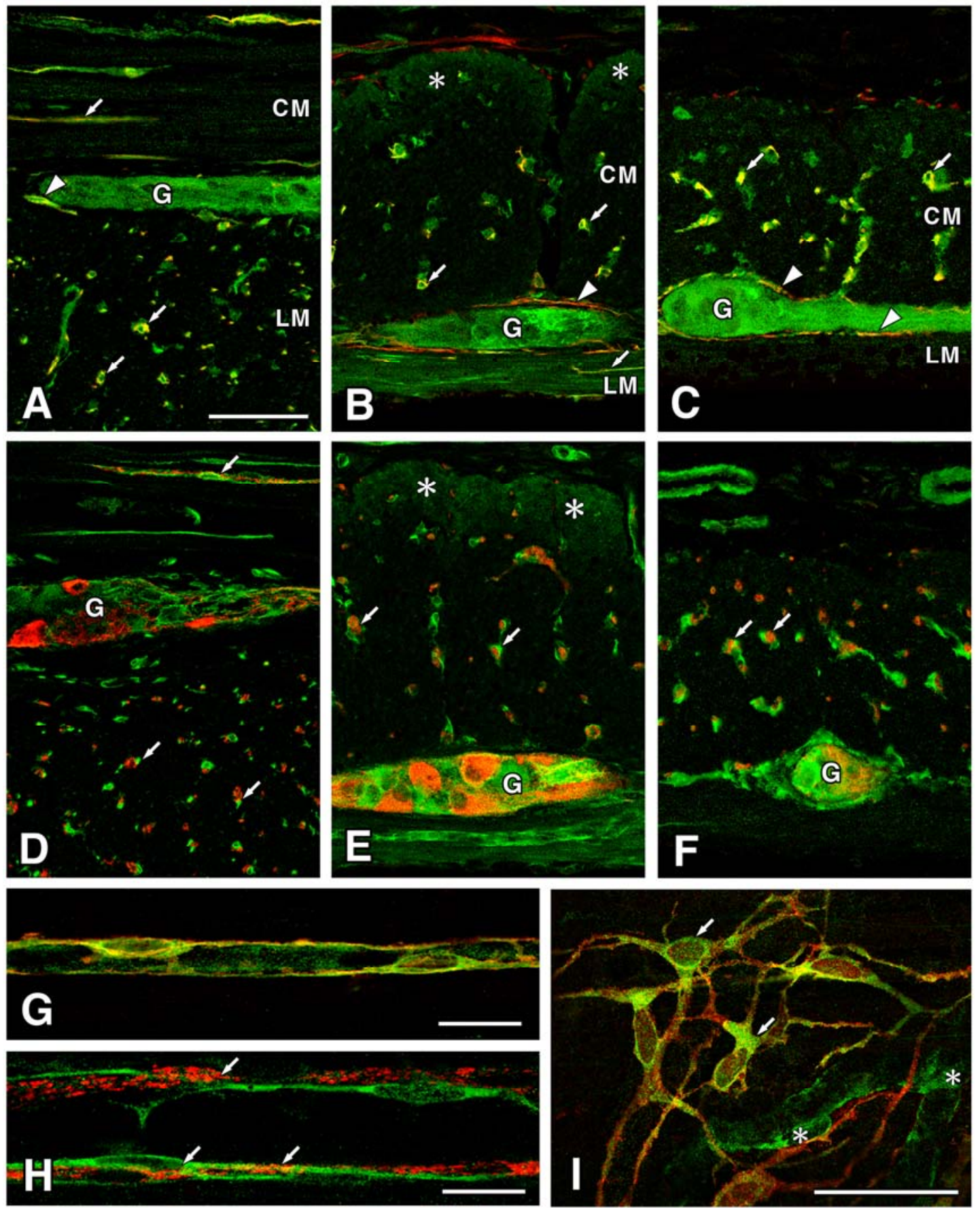

(Fig. 5) 

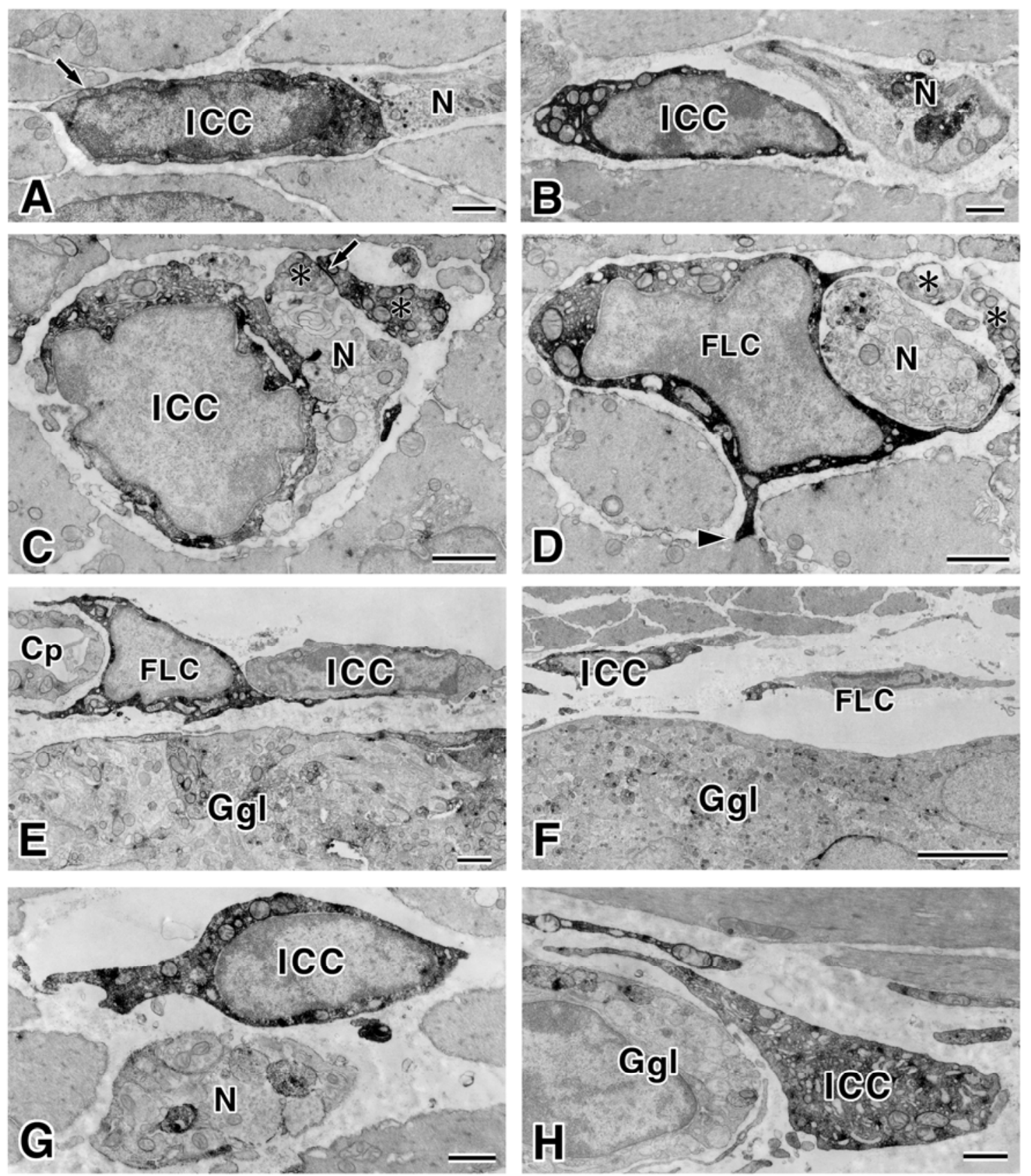

(Fig. 6) 


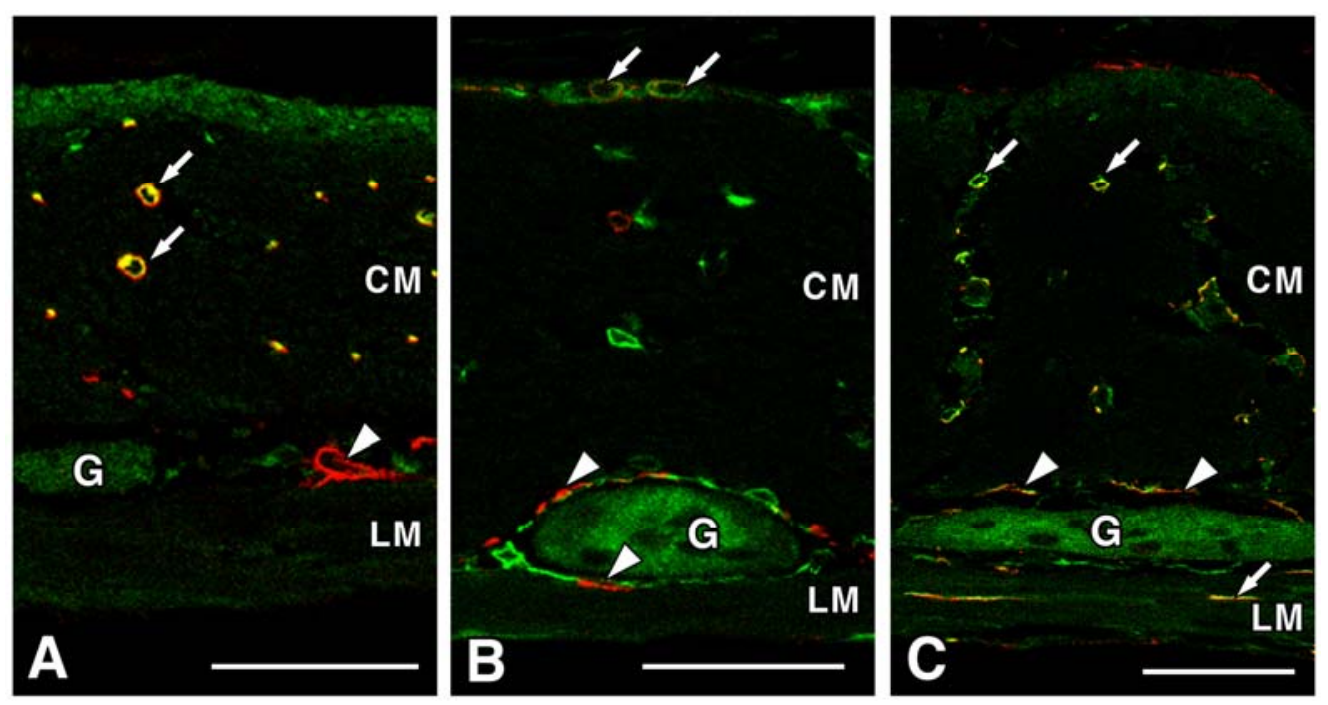

(Fig. 7) 